\title{
Bibliometric analysis of the trends of Zika related research from 2015 to 2017
}

Yong-Dae Gwon ${ }^{1}$, and Magnus Evander ${ }^{1 *}$

${ }^{1}$ Department of Clinical Microbiology, Virology, Umeå University, Umeå, Sweden

* Correspondence: magnus.evander@umu.se

Keywords: Zika virus, bibliometrics, research trends, emerging infectious disease 


\section{Abstract}

\section{Background}

Zika virus (ZIKV) is a mosquito-borne disease discovered in 1947, which did not cause public concern for the next 68 years. However, when ZIKV emerged in Brazil 2015 the attention increased rapidly. The announcement by Brazilian authorities, that ZIKV infection was associated with severe congenital disease e.g. microcephaly, surged public interest. Because of the accumulation of evidence that showed the magnitude of the ZIKV outbreak in the Americas, the World Health Organization declared a Public Health Emergency of International Concern February 1, 2016.

\section{Results}

During 2015-2017, we witnessed one of the most active and cooperated research responses against an emerging disease. To investigate the impact of ZIKV research during those years we decided to perform a bibliometric analysis of ZIKV research. The search for research articles on ZIKV was performed by bibliometric analysis from the scientific databases PubMed and Scopus. We found that the number of ZIKV related publications increased 38-41 times in 2016-2017 compared to 2015. During the three years there was a temporal shift in ZIKV research trends, from reports of ZIKV case studies and diagnostic methods, to development of ZIKV prevention and treatment. In addition, the number of countries involved in ZIKV research increased from 25 in 2015 to 111 in 2016 and 139 in the following year, showing that ZIKV research became global during three years.

\section{Conclusions}

The results from our study highlighted the importance of gathering public interest to global health issues, and how it can act as a powerful catalyzer to trigger the research field. However, despite the progress in ZIKV research, many questions remain to be addressed to accelerate the development of effective ZIKV countermeasures. Nevertheless, as long as we remember the importance of support and collaboration that we have experienced during the multidisciplinary effort against the current ZIKV outbreak, we will have an idea on how to handle the next inevitable and yet unknown infectious disease threat. 


\section{Background}

Zika virus (ZIKV) is a mosquito-borne virus in the family Flaviviridae, genus Flavivirus. Mainly mosquitoes from the Aedes genus are zoonotic vectors [1, 2]. After the first discovery 1947 in Uganda, Africa, ZIKV human infection has been found in Asia, the Pacific, and Americas [3, 4].

In 2007, a ZIKV outbreak was reported on Yap Island and nearby islands in Micronesia [5]. It later spread eastward in the Pacific Ocean and in 2015 it spread to the Americas with the initial identification in Brazil [6, 7]. After the 2015 introduction to the Americas, it was shown that ZIKV infection had a strong association to microcephaly in newborns, neurological disorders in adults (such as Guillain-Barré syndrome), as well as a potential for sexual transmission [8-10]. Due to the accumulation of evidence that showed the magnitude of the ZIKV outbreak in Americas, the World Health Organization (WHO) declared a Public Health Emergency of International Concern (PHEIC) on $1^{\text {st }}$ February 2016, and agreed on the urgent need to coordinate international efforts to investigate and understand this relationship better $[11,12]$.

According to the Organisation for Economic Co-operation and Development (OECD), bibliometrics is a statistical analysis of books, articles, or other publications to measure the "output" of individuals/research teams, institutions, and countries, to identify national and international networks, and to map the development of new (multi-disciplinary) fields of science and technology [13]. Scientific publication databases (e.g. Pubmed, Scopus, and Web of Science, etc) has been widely used for bibliometric analysis to assess the value of published scientific output in worldwide [14].

Therefore, we chose a bibliometric analysis method by using scientific publication databases to follow the trend of ZIKV research around the world. For analysis, we have collected publications for 2015-2017 and examined the trends of ZIKV research with various parameters. 


\section{Methods}

\section{Information sources and search strategy}

To conduct the bibliometric analysis, we chose two different database sources, Pubmed and Scopus, for data extraction of publications related to ZIKV.

The search strategy was designed to find publication data about ZIKV from the scientific databases of published peer-reviewed studies. The search strings for the two different databases were selected from what has previously been used in a systematic review article from WHO [15]. The Pubmed search string was: zika [Title/Abstract] OR ZIKV [Title/Abstract] OR zika virus [MeSH Terms] OR zika virus infection [MeSH Terms]. The Scopus search string was: ZIKA [Title/Abstract/Keyword] OR ZIKV [Title/Abstract/Keyword] OR “zika virus” [Keyword] OR “zika virus infection” [Keyword].

We conducted our search for articles published from January $1^{\text {st }} 2015$ to December $31^{\text {st }} 2017$. Data for further analysis were selected and extracted, and then related to different parameters. All data were extracted April 2, 2018.

\section{Generation of the bibliometric summary report}

Profiles Research Networking Software (Profiles RNS) is an NIH-funded open source tool to speed-up the process of finding researchers with specific areas of expertise for collaboration and professional networking [16]. The bibliometric summary report tool from Profiles RNS was used to calculate common metrics, including citation counts and h-index, from given a list of Pubmed IDs derived from Pubmed, a database of the U.S. National Library of Medicine by using Entrez Direct (EDirect) utility from a UNIX terminal window [17]. The generated report was analyzed for data sorting and represented as one of the parameters in this study.

\section{Data Extraction}

To extract the ZIKV related publications for 2015-2017, we used Scopus with the search string mentioned above. The results were extracted in an Excel CSV document format. Next, we sorted out the result by analytic parameters (e.g. publication type, journal type, country, citation number, and core author), and the data used in this study is provided in the additional excel file (Additional file 1). 


\section{Generation of geographic information system (GIS) maps}

User-friendly GIS-maps [18], were generated to display the distribution of the publications. To generate and illustrate the GIS maps, we selected the R programming language with the "rworldmap" plug-in which is a package for visualizing global-scale data, concentrating on data referenced by country codes or gridded at half-degree resolution [19].

\section{Data visualization}

All data visualization were performed by using GraphPad 7.0 (CA, USA). Adobe Illustrator CC 2017 (CA, USA) was used for editing visualized data. 


\section{Results}

\section{The ZIKV research field was fuelled by surged public interest}

Until the signal flares alerted us about the new emergence of ZIKV in Americas, ZIKV was far from the public interest and poorly studied since 1947 [20]. Unexpectedly, the outbreak in the Americas was associated not only with mild infection, but also with severe congenital disease, particularly microcephaly in newborn infants. [21]

In addition, photographs that focused on a mother holding her newborn with microcephaly caused by ZIKV infection during pregnancy, caused sympathy and concerned authorities [22]. Once the public interest was raised, it led to a global awareness and actions for aiming to prevent the new ZIKV outbreak. Particularly in science, many research fields were fuelled to investigate and better understand all aspects of ZIKV.

We, as witnesses of one of the most rapid and organized research responses against an emerging disease, chose to compare the number of scientific publications to highlight the increase of research in the last three years. In 2015, there was an average number of 51 ZIKV related publication and the number then increased rapidly in 2016-2017 (38.3 and 40.6 times, respectively) (Figure 1).

This result indirectly showed how active the research has been since the start of the ZIKV pandemic in Americas. However, the time for publication process in journals may vary from months to years. Thus, the publications from 2015 may include the research of yesteryear, but even if we consider the time for the publication process for 2015, there were less than 100 publications. The declaration of a public health emergency by WHO did not only bring public interest to ZIKV research, but also an increase of ZIKV research funding. Accordingly, the number of publications increased dramatically in the past two years. 


\section{Pubmed}

Scopus

$\mathrm{n}=\mathbf{3 8}$

2015

2016

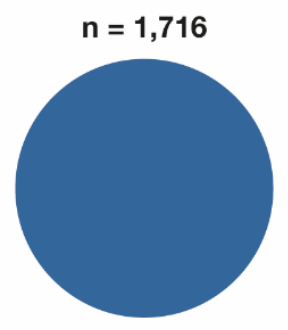

2017

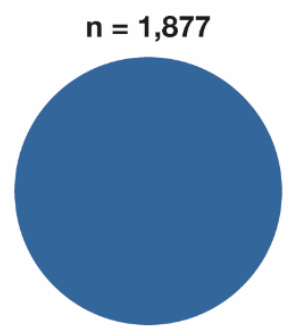

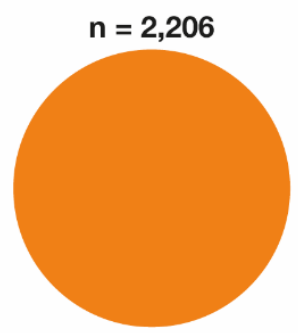

$\mathrm{n}=64$

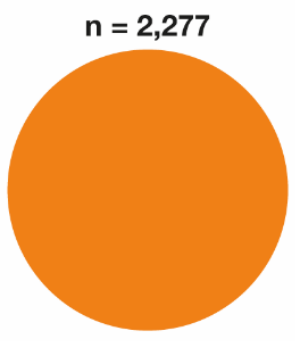

\section{Major event in ZIKV timeline ${ }^{(1)}$}

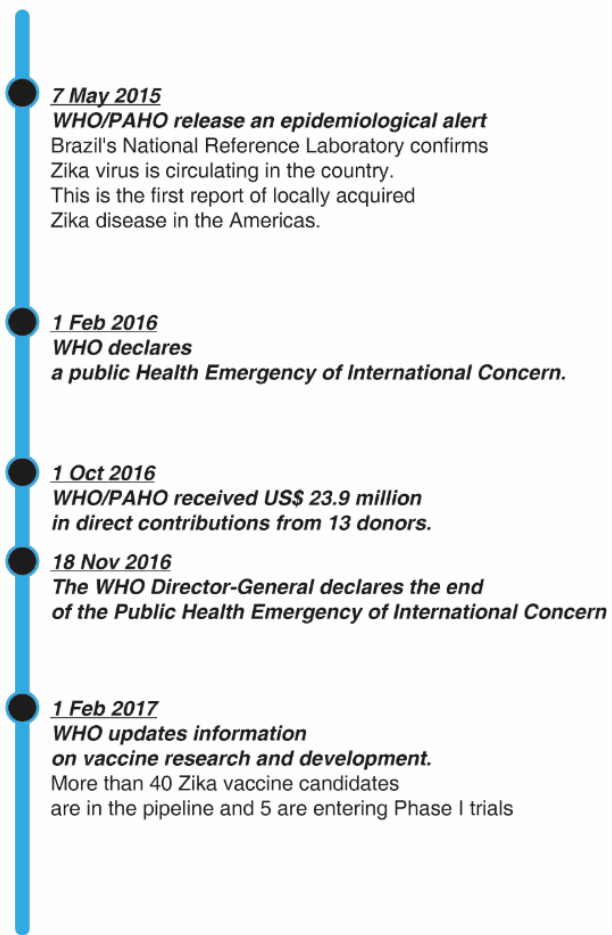

Figure 1. Zika virus associated publications 2015-2017

(1) The major events in the figure was selected from "WHO - The History of Zika Virus" [23] 


\section{ZIKV research field moved from case reports to prospective studies}

As a further approach, we decided to generate a bibliometric analysis summary from the Profile RNS website to monitor the trend of ZIKV research. We extracted the data sorted by publication types to investigate the proportion of publication types for the total ZIKV related publications in 2015-2017.

Among various types of publications, we selectively investigated journal articles and case reports. In the case of ZIKV related journal articles, the proportion increased from 35.5\% in $2015(\mathrm{n}=27)$ to $51.3 \%$ in 2016 ( $n=1202)$, and to $66.8 \%$ of journal articles in $2017(n=1636)$. On the other hand, the proportion of case reports with ZIKV connections decreased from $14.4 \%$ in $2015(n=11)$ to $4.3 \%$ in $2016(n=102)$, and to $1.6 \%$ in $2017(\mathrm{n}=40)$ (Figure 2). In addition, we analyzed the top 20 journals for ZIKV publications during 2015-2017. Most journals where ZIKV related research was published in 2015 had a clinical and surveillance aspect, which shifted to journals that published prospective studies during 2016-2017 (Figure $3)$.

To find out which articles that were most cited, we extracted the 20 highest cited articles. The result showed that articles about case reports, diagnostic methods, and potential sexual transmission of ZIKV were the most cited in 2015. In 2016, the articles regarding the relationship between ZIKV infection and microcephaly, the relationship between ZIKV infection and Guillain-Barré Syndrome, and development of ZIKV animal model were highly cited. Studies of ZIKV vaccine, ZIKV antiviral treatment, and understanding of ZIKV pathogenicity and tropism were most cited in 2017 (Table 1).

Overall, when we compared the most cited articles with the pattern of decrease in case reports and increase in total journal articles, we concluded that the ZIKA research trend has shifted from reports of ZIKV case studies and diagnostic methods, to development of ZIKV prevention and treatment, most probably by the gradually accumulated knowledge of ZIKV through the extensive research. 

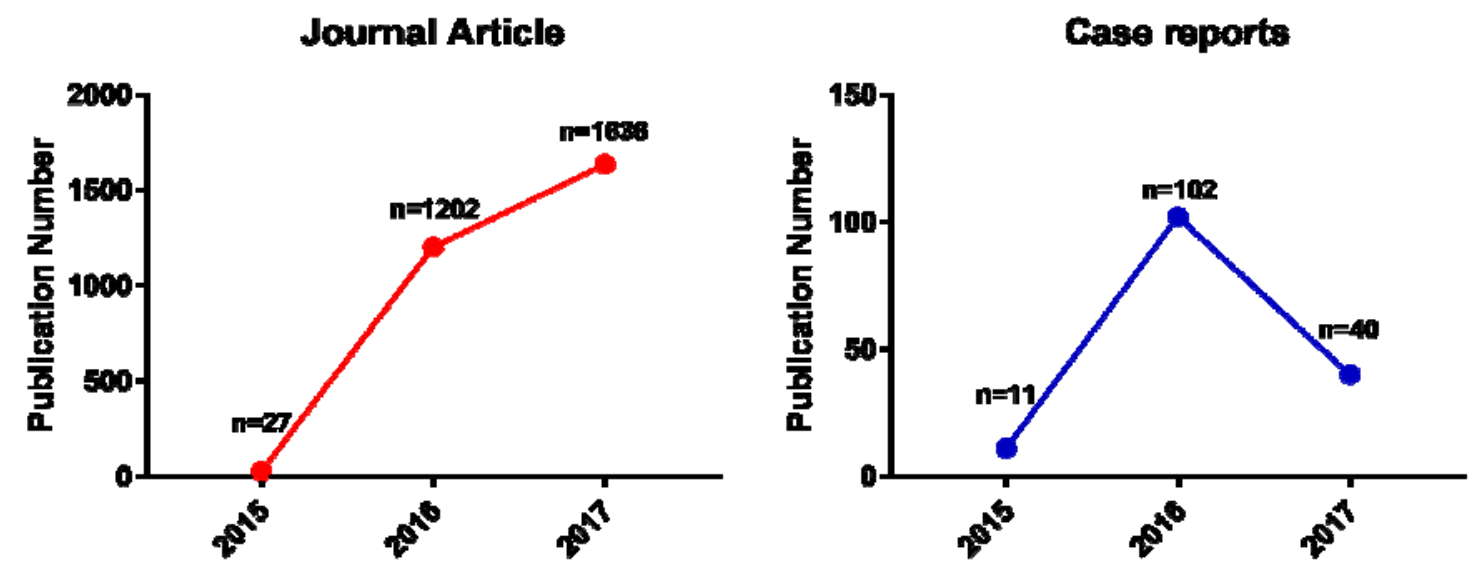

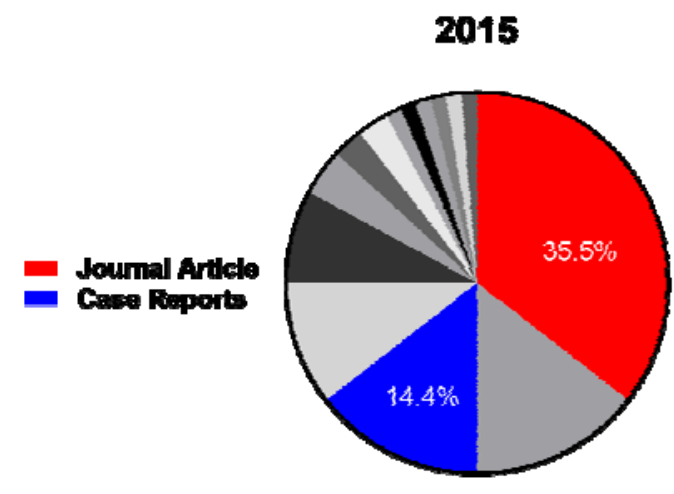

Total $=76$

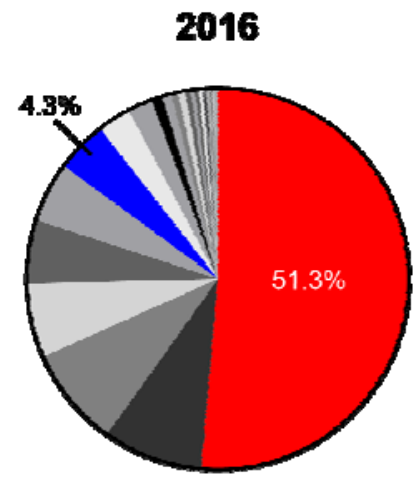

Total $=\mathbf{2 3 3 9}$

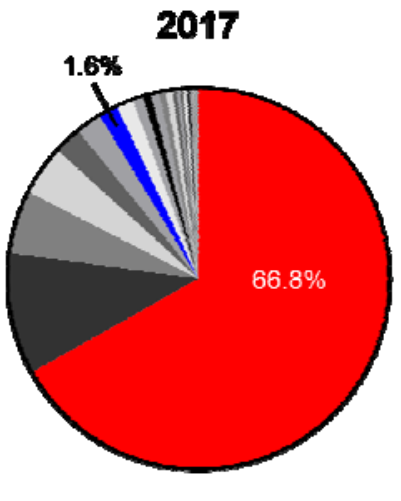

Total $=2448$

Figure 2. Publication type for Zika virus articles 2015-2017

The publication type was based on the categories assigned to an article in Medline/PubMed. There can be more than one publication type per article, so a single publication might be listed more than once in the table below. Thus, the numbers of publication might add up to more than the total number of publications. The publication types were based on data from Profiles RNS. A full list of types and numbers are available in Additional file 1. 

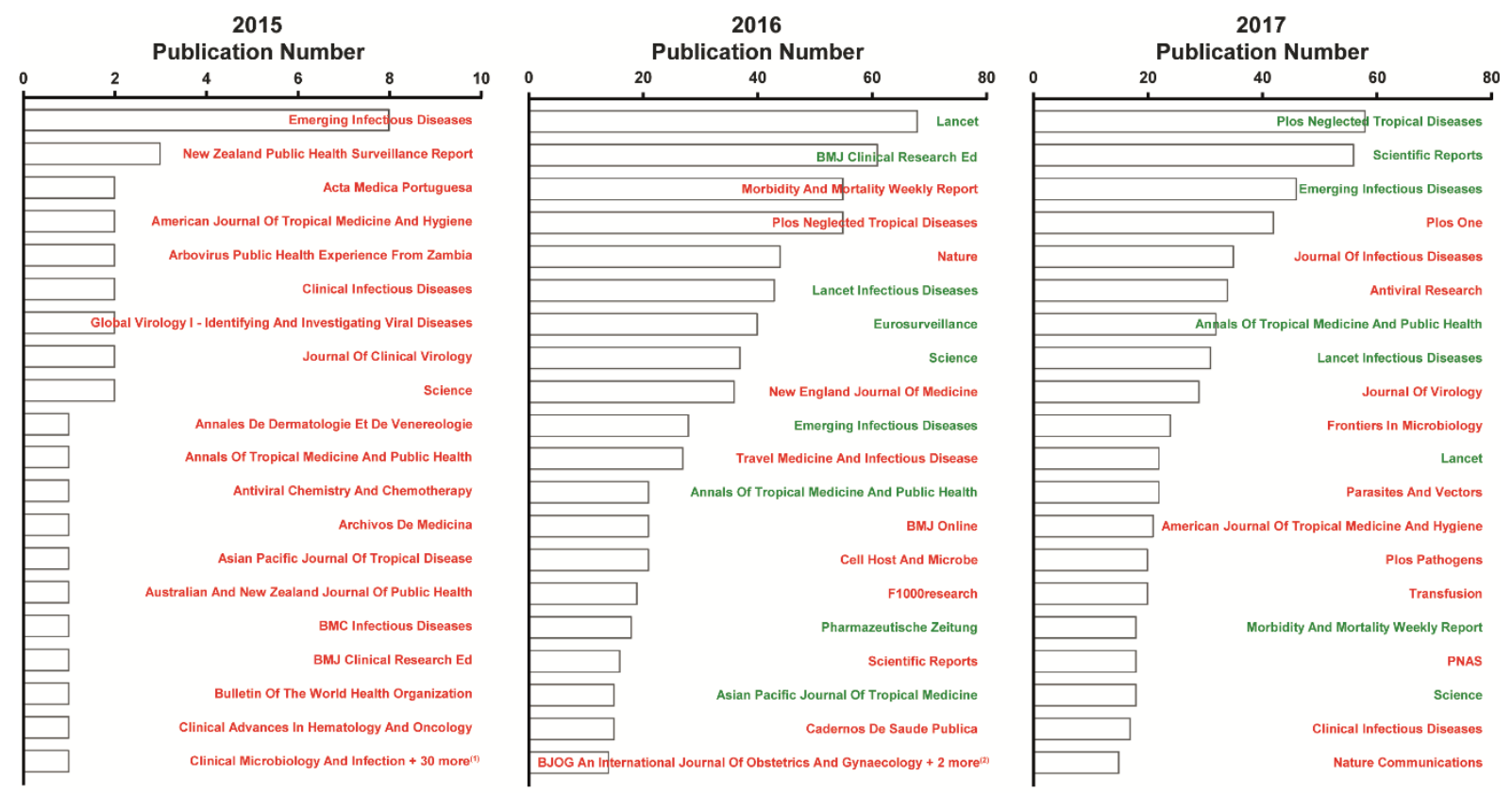

Green Color - Also found in yesteryear Red Color - Newly pop-up

\section{Figure 3. Top 20 journals publishing Zika virus related research 2015-2017}

${ }^{(1)}$ In 2015, a total of 41 journals had only a single Zika virus (ZIKV) publication. Of the 41 journals with a single ZIKV publication, we selected 11 journals for the figure (by alphabetical order). Since all data in this bibliometric study were collected from 2015, all journals in the 2015 graph were marked as newly pop-up. ${ }^{(2)}$ In 2016, a total of three journals had fourteen ZIKV publication. Of the three journals with a single ZIKV publication, we selected one journal for the figure (by alphabetical order). A full list of journals is available in Additional file 1. 


\section{The geographic distribution of ZIKV publications points to globalization of ZIKV research.}

We extracted publications by country and generated a world map displaying the geographic distribution of ZIKV publications in 2015-2017. In 2015, 25 countries published ZIKV research, it increased to 111 in 2016 and 139 in the following year, showing that ZIKV research became global during three years (Figure 4).

The United States of America (USA) showed the highest number of ZIKV publications for the whole period 2015-2017, followed by Brazil, the United Kingdom, China, and France. A similar pattern was observed for the top 20 authors with ZIKV related publications, where USA showed the highest number of authors, followed by Brazil, China, and France (Table 2). In addition, a total of 43 authors produced more than 16 articles in 2015-2017 (rank no.1 was 136 articles by Wiwanitkit V).

One possible explanation is an increase in ZIKV research funding. In USA, the budget for Ebola virus research was shifted to ZIKV research [24]; the European Union invested funded three research consortia: ZikaPLAN, ZIKAction, ZikAlliance [25]; Brazil, the first site of ZIKV infection in the Americas and host of the World Cup in football in 2016, was provided with emergency research funding [26]. The global support for ZIKV research during this period most probably was a key factor in the increased number of publications globally. It would be interesting to merge the actual budget of ZIKV research in each country for 2015-2017 with the geographic distribution of publications to get a clearer picture for the ZIKV research trend. 


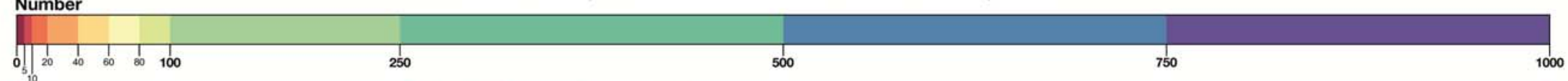

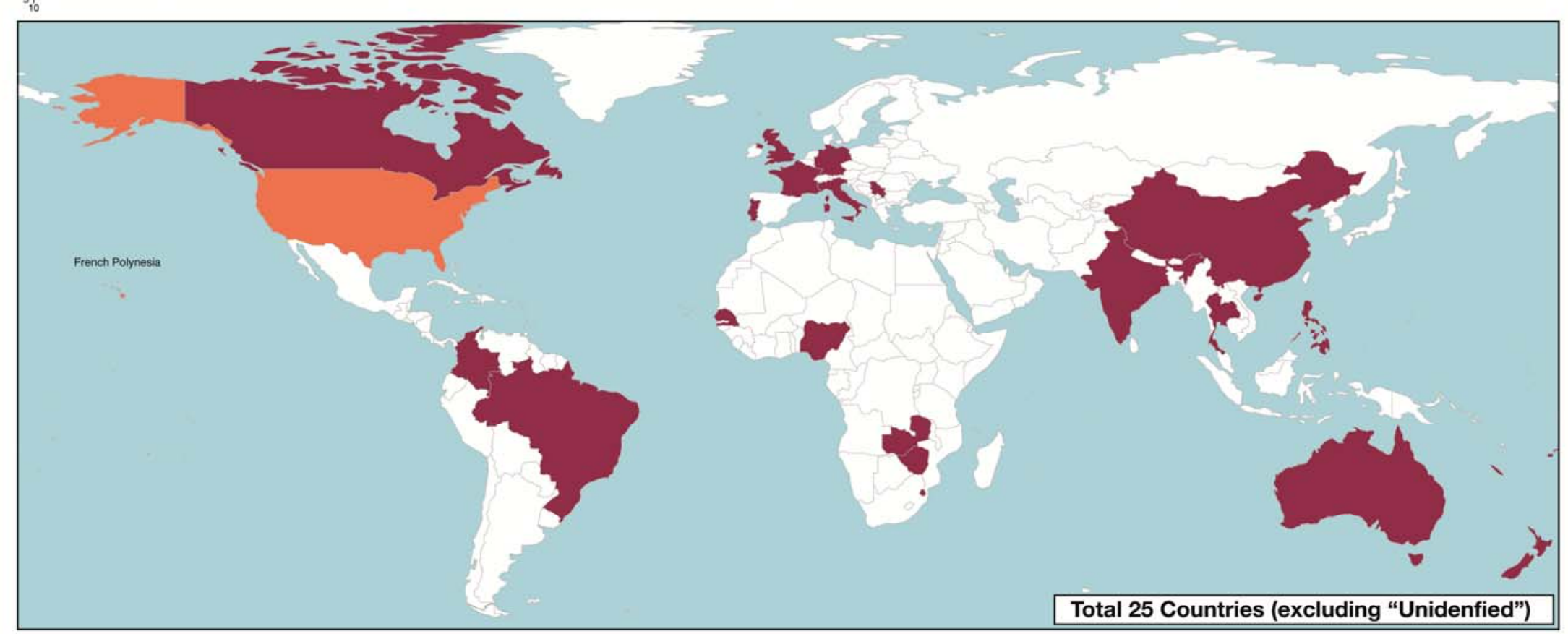

\section{Top 20 Countries (Actual number)}
1. USA (15)
2. French Polynesia (7)
3. Australia, Brazil, France, Germany, Thailand (5)
8. Colombia, Zambia (3)
10. Canada, China, Italy, New Caledonia, Senegal, Switzerland, United Kingdom (2)
17. Fiji, India, New Zealand, Nigeria, Philippines, Portugal, Serbia, Singapore, Zimbabwe (1) 


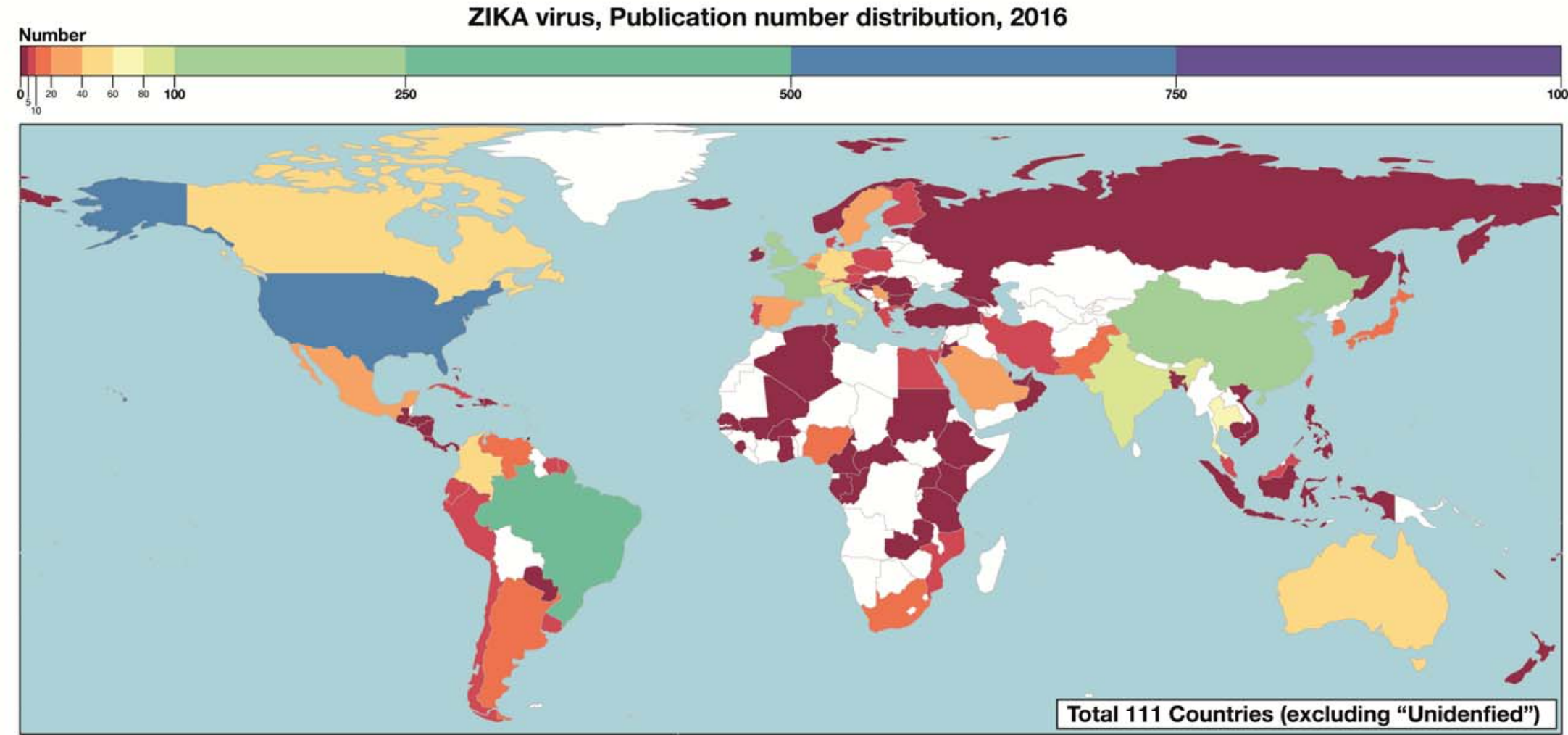

Top 20 Countries (Actual number)

\begin{tabular}{|lll|}
\hline 1. USA (690) & 8. Thailand (68) & 15. Spain (37) \\
2. Brazil (285) & 9. Germany (56) & 16. French Polynesia (34) \\
3. United Kingdom (157) & 10. Canada (55) & 17. Netherlands (32) \\
4. France (131) & 11. Switzerland (50) & 18. Saudi Arabia (27) \\
5. China (113) & 12. Colombia (47) & 19. Serbia (26) \\
6. Italy (83) & 13. Australia (41) & 20. Mexico, Sweden (22) \\
7. India (81) & 14. Singapore (38) \\
\hline
\end{tabular}




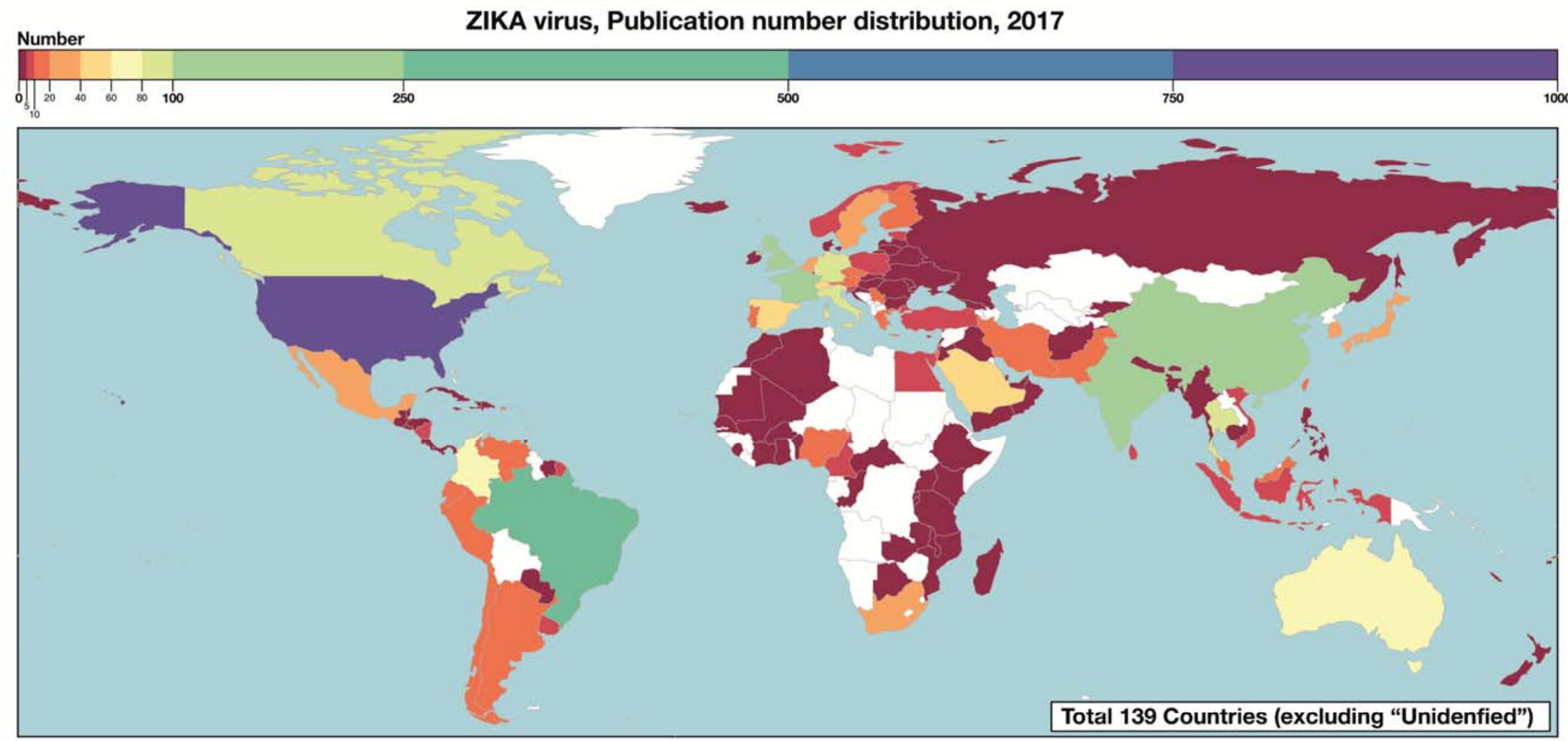

Top 20 Countries (Actual number)

\begin{tabular}{|lll|}
\hline 1. USA (974) & 9. Canada (85) & 18. Mexico (30) \\
2. Brazil (298) & 10. Germany (81) & 19. Belgium, Japan, South Korea (27) \\
3. China (194) & 11. Australia, Colombia (65) & \\
4. United Kingdom (148) & 13. Singapore, Switzerland (58) \\
5. France (116) & 15. Spain (50) & \\
6. India (115) & 16. Saudi Arabia(41) & \\
7. Italy, Thailand (100) & 17. Netherlands (38) & Full list is available in Additional file 1 \\
\hline
\end{tabular}

Figure 4. Geographic distribution of Zika virus publications 2015-2017 


\section{Discussion}

Through the bibliometric analysis of Zika related publications, we extracted information describing different factors. The outcome highlighted the importance of gathering public interest to global health issues, and how it can act as a powerful catalyzer to trigger the research field. We also learned that the research efforts resulting from the start of the ZIKV epidemic in the Americas could been seen as an example of global collaboration and efforts to solve a problem when the world is in danger.

After the ZIKV outbreak, the direction of the research started with sharing of information about the risk of the disease, patient cases, and carrying out basic research for the general understanding of the disease. Then it moved to application research based on the understanding from previous basic research, to suggest solutions for the disease (such as vaccines and antiviral treatments). According to the WHO vaccine pipeline tracker, several ZIKV vaccine candidates are currently in clinical phase 1 or 2 [27].

The geographic information showed that during the years after the outbreak of ZIKV in 2015, most countries around the world have taken steps to combat ZIKV and have actively performed research. ZIKV has rapidly become the object of intense investigation by the international research community [20]. However, despite the progress in ZIKV research, many questions remain to be addressed to accelerate the development of effective ZIKV countermeasures

\section{Conclusions}

Through bibliometric analysis of ZIKV related publication for 2015-2017, we have provided an analysis of the ZIKV research trend. Geographic distribution showed that publications from USA, Brazil, and Europe led the scientific production on ZIKV research. It would be interesting to investigate further directions by combining data analyzed by other sociological viewpoints, e.g. the national budget of ZIKV research in different countries. However, we have to remember the importance of support and collaboration from a multidisciplinary effort that is ongoing against the current ZIKV outbreak, to better know how to handle the next inevitable and yet unknown infectious disease threat 


\section{References}

1. Kindhauser MK, Allen T, Frank V, Santhana RS, Dye C. Zika: the origin and spread of a mosquitoborne virus. Bull World Health Organ. 2016; 94:675-686C.

2. Braack L, Gouveia de Almeida AP, Cornel AJ, Swanepoel R, de Jager C. Mosquito-borne arboviruses of African origin: review of key viruses and vectors. Parasit Vectors. 2018; 11:29.

3. Musso D, Gubler DJ. Zika Virus. Clin Microbiol Rev. 2016; 29:487-524.

4. Dick GW, Kitchen SF, Haddow AJ. Zika virus. I. Isolations and serological specificity. Trans R Soc Trop Med Hyg. 1952; 46:509-520.

5. Duffy MR, Chen TH, Hancock WT, Powers AM, Kool JL, Lanciotti RS, Pretrick M, Marfel M, Holzbauer S, Dubray C, et al. Zika virus outbreak on Yap Island, Federated States of Micronesia. N Engl J Med. 2009; 360:2536-2543.

6. Hamer DH, Barbre KA, Chen LH, Grobusch MP, Schlagenhauf P, Goorhuis A, van Genderen PJ, Molina I, Asgeirsson H, Kozarsky PE, et al. Travel-Associated Zika Virus Disease Acquired in the Americas Through February 2016: A GeoSentinel Analysis. Ann Intern Med. 2017; 166:99-108.

7. Zanluca C, Melo VC, Mosimann AL, Santos GI, Santos CN, Luz K. First report of autochthonous transmission of Zika virus in Brazil. Mem Inst Oswaldo Cruz. 2015; 110:569-572.

8. de Araujo TV, Rodrigues LC, de Alencar Ximenes RA, de Barros Miranda-Filho D, Montarroyos UR, de Melo AP, Valongueiro S, de Albuquerque MF, Souza WV, Braga C, et al. Association between Zika virus infection and microcephaly in Brazil, January to May, 2016: preliminary report of a case-control study. Lancet Infect Dis. 2016; 16:1356-1363.

9. Avelino-Silva VI, Martin JN. Association between Guillain-Barre syndrome and Zika virus infection. Lancet. 2016; 387:2599.

10. Musso D, Roche C, Robin E, Nhan T, Teissier A, Cao-Lormeau VM. Potential sexual transmission of Zika virus. Emerg Infect Dis. 2015; 21:359-361.

11. Roos RP. Zika Virus-A Public Health Emergency of International Concern. JAMA Neurol. 2016; 73:1395-1396.

12. WHO. WHO Director-General summarizes the outcome of the Emergency Committee regarding clusters of microcephaly and Guillain-Barré syndrome. http://www.who.int/mediacentre/news/statements/2016/emergency-committee-zikamicrocephaly/en/. Accessed 1 Feb 2016.

13. OECD. OECD Frascati Manual. Sixth edition edn. OECD; 2002: Annex 7, paras. 20-22, p. 203. 
14. Agarwal A, Durairajanayagam D, Tatagari S, Esteves SC, Harlev A, Henkel R, Roychoudhury S, Homa S, Puchalt NG, Ramasamy R, et al. Bibliometrics: tracking research impact by selecting the appropriate metrics. Asian J Androl. 2016; 18:296-309.

15. Krauer F, Riesen M, Reveiz L, Oladapo OT, Martinez-Vega R, Porgo TV, Haefliger A, Broutet NJ, Low N. Zika Virus Infection as a Cause of Congenital Brain Abnormalities and Guillain-Barre Syndrome: Systematic Review. PLoS Med. 2017; 14:e1002203.

16. Profiles Research Networking Software. Harvard University. 2018. http://profiles.catalyst.harvard.edu/. Accessed 22 Mar 2018.

17. Kans J. Entrez Direct: E-utilities on the UNIX Command Line. https://www.ncbi.nlm.nih.gov/books/NBK179288/. Accessed 28 Dec 2017.

18. Graham SR, Carlton C, Gaede D, Jamison B. The benefits of using geographic information systems as a community assessment tool. Public Health Rep. 2011; 126:298-303.

19. Andy S. rworldmap: A New R package for Mapping Global Data. The R Journal. 2011; 3:35-43.

20. Erbelding E, Cassetti C. Zika Virus and Future Research Directions. J Infect Dis. 2017; 216:S991S994.

21. Culjat M, Darling SE, Nerurkar VR, Ching N, Kumar M, Min SK, Wong R, Grant L, Melish ME. Clinical and Imaging Findings in an Infant With Zika Embryopathy. Clin Infect Dis. 2016; 63:805811.

22. Vogel G. Zika virus kills developing brain cells. Science. 2016; doi:10.1126/science.aaf4148.

23. WHO. The History of Zika Virus. http://www.who.int/emergencies/zika-virus/history/en/. Accessed 26 Mar 2018.

24. NBC. Congress Finally Passes Zika Funding Bill; Provides $\$ 1.1$ Billion. https://www.nbcnews.com/storyline/zika-virus-outbreak/congress-finally-passes-zika-funding-billn656866. Accessed 29 Sep 2016.

25. EU. European Union invests $€ 45$ million into research to combat the Zika disease. http://ec.europa.eu/research/index.cfm?pg=newsalert\&year=2016\&na=na-211016. Accessed 21 Oct 2016.

26. REUTERS. Brazil's BNDES provides $\$ 136$ million to fight Zika, related illnesses. https://uk.reuters.com/article/us-health-zika-brazil/brazils-bndes-provides-136-million-to-fight-zikarelated-illnesses-idUKKCNOWP2DU. Accessed 23 Mar 2016.

27. WHO vaccine tracker. 2018. http://www.who.int/immunization/research/vaccine pipeline tracker spreadsheet/en/. Accessed 22 Mar 2018. 
Table 1. Top 20 cited Zika virus related publications 2015 to 2017

2015

\begin{tabular}{|c|c|c|c|c|c|}
\hline & Author & Article title & Source & $\begin{array}{l}\text { Cited } \\
\text { by }\end{array}$ & $\begin{array}{l}\text { Pubmed } \\
\text { ID }\end{array}$ \\
\hline 1 & Musso D., et al. & $\begin{array}{l}\text { Potential sexual transmission of zika } \\
\text { virus }\end{array}$ & $\begin{array}{l}\text { Emerging Infectious } \\
\text { Diseases }\end{array}$ & 488 & 25625872 \\
\hline 2 & Zanluca C., et al. & $\begin{array}{l}\text { First report of autochthonous } \\
\text { transmission of Zika virus in Brazil }\end{array}$ & $\begin{array}{l}\text { Memorias do Instituto } \\
\text { Oswaldo Cruz }\end{array}$ & 396 & 26061233 \\
\hline 3 & Campos G.S., et al. & Zika virus outbreak, Bahia, Brazil & $\begin{array}{l}\text { Emerging Infectious } \\
\text { Diseases }\end{array}$ & 379 & 26401719 \\
\hline 4 & Hamel R., et al. & $\begin{array}{l}\text { Biology of Zika virus infection in human } \\
\text { skin cells }\end{array}$ & Journal of Virology & 324 & 26085147 \\
\hline 5 & $\begin{array}{l}\text { Gourinat A.-C., et } \\
\text { al. }\end{array}$ & Detection of zika virus in urine & $\begin{array}{l}\text { Emerging Infectious } \\
\text { Diseases }\end{array}$ & 302 & 25530324 \\
\hline 6 & Musso D., et al. & Detection of Zika virus in saliva & $\begin{array}{l}\text { Journal of Clinical } \\
\text { Virology }\end{array}$ & 236 & 26071336 \\
\hline 7 & Musso D., et al. & $\begin{array}{l}\text { Zika virus: Following the path of dengue } \\
\text { and chikungunya? }\end{array}$ & The Lancet & 201 & 26194519 \\
\hline 8 & Musso D. & $\begin{array}{l}\text { Zika virus transmission from French } \\
\text { Polynesia to Brazil }\end{array}$ & $\begin{array}{l}\text { Emerging Infectious } \\
\text { Diseases }\end{array}$ & 137 & 26403318 \\
\hline 9 & $\begin{array}{l}\text { Dupont-Rouzeyrol } \\
\text { M., et al. }\end{array}$ & $\begin{array}{l}\text { Co-infection with zika and dengue } \\
\text { viruses in } 2 \text { patients, New Caledonia, } \\
2014\end{array}$ & $\begin{array}{l}\text { Emerging Infectious } \\
\text { Diseases }\end{array}$ & 136 & 25625687 \\
\hline 10 & Buathong R., et al. & $\begin{array}{l}\text { Detection of zika virus infection in } \\
\text { Thailand, 2012-2014 }\end{array}$ & $\begin{array}{l}\text { American Journal of } \\
\text { Tropical Medicine and } \\
\text { Hygiene }\end{array}$ & 115 & 26101272 \\
\hline 11 & Cardoso C.W., et al. & $\begin{array}{l}\text { Outbreak of Exanthematous Illness } \\
\text { associated with Zika, Chikungunya, and } \\
\text { Dengue viruses, Salvador, Brazil }\end{array}$ & $\begin{array}{l}\text { Emerging Infectious } \\
\text { Diseases }\end{array}$ & 109 & 26584464 \\
\hline 12 & Zammarchi L., et al. & $\begin{array}{l}\text { Zika virus infections imported to Italy: } \\
\text { Clinical, immunological and virological } \\
\text { findings, and public health implications }\end{array}$ & $\begin{array}{l}\text { Journal of Clinical } \\
\text { Virology }\end{array}$ & 103 & 25600600 \\
\hline 13 & Diagne C.T., et al. & $\begin{array}{l}\text { Potential of selected Senegalese Aedes } \\
\text { spp. mosquitoes (Diptera: Culicidae) to } \\
\text { transmit Zika virus }\end{array}$ & BMC Infectious Diseases & 83 & 26527535 \\
\hline 14 & Zammarchi L., et al. & $\begin{array}{l}\text { Zika virus infection in a traveller } \\
\text { returning to europe from Brazil, march } \\
2015\end{array}$ & Eurosurveillance & 79 & 26084316 \\
\hline 15 & $\begin{array}{l}\text { Rodríguez-Morales } \\
\text { A.J. }\end{array}$ & $\begin{array}{l}\text { Zika: The new arbovirus threat for latin } \\
\text { america }\end{array}$ & $\begin{array}{l}\text { Journal of Infection in } \\
\text { Developing Countries }\end{array}$ & 68 & 26142684 \\
\hline 16 & Tappe D., et al. & $\begin{array}{l}\text { Acute Zika virus infection after travel to } \\
\text { Malaysian Borneo, September } 2014\end{array}$ & $\begin{array}{l}\text { Emerging Infectious } \\
\text { Diseases }\end{array}$ & 64 & 25898277 \\
\hline 17 & $\begin{array}{l}\text { Joob B., Wiwanitkit } \\
\text { V. }\end{array}$ & $\begin{array}{l}\text { Zika virus infection and dengue: A new } \\
\text { problem in diagnosis in a dengue- } \\
\text { endemic area }\end{array}$ & $\begin{array}{l}\text { Annals of Tropical } \\
\text { Medicine and Public } \\
\text { Health }\end{array}$ & 58 & \\
\hline 18 & Leung G.H.Y., et al. & $\begin{array}{l}\text { Zika virus infection in Australia } \\
\text { following a monkey bite in Indonesia }\end{array}$ & $\begin{array}{l}\text { Southeast Asian Journal } \\
\text { of Tropical Medicine and } \\
\text { Public Health }\end{array}$ & 57 & 26521519 \\
\hline 19 & Alera M.T., et al. & Zika virus infection, philippines, 2012 & $\begin{array}{l}\text { Emerging Infectious } \\
\text { Diseases }\end{array}$ & 57 & 25811410 \\
\hline 20 & Aubry M., et al. & $\begin{array}{l}\text { Seroprevalence of arboviruses among } \\
\text { blood donors in French Polynesia, 2011- } \\
2013\end{array}$ & $\begin{array}{l}\text { International Journal of } \\
\text { Infectious Diseases }\end{array}$ & 55 & 26482390 \\
\hline
\end{tabular}




\begin{tabular}{|c|c|c|c|c|c|}
\hline & Author & Article title & Source & $\begin{array}{l}\text { Cited } \\
\text { by }\end{array}$ & $\begin{array}{l}\text { Pubmed } \\
\text { ID }\end{array}$ \\
\hline 1 & Mlakar J., et al. & Zika virus associated with microcephaly & $\begin{array}{l}\text { New England Journal of } \\
\text { Medicine }\end{array}$ & 815 & 26862926 \\
\hline 2 & $\begin{array}{l}\text { Cao-Lormeau V.- } \\
\text { M., et al. }\end{array}$ & $\begin{array}{l}\text { Guillain-Barré Syndrome outbreak } \\
\text { associated with Zika virus infection in } \\
\text { French Polynesia: A case-control study }\end{array}$ & The Lancet & 653 & 26948433 \\
\hline 3 & $\begin{array}{l}\text { Rasmussen S.A., et } \\
\text { al. }\end{array}$ & $\begin{array}{l}\text { Zika virus and birth defects - Reviewing } \\
\text { the evidence for causality }\end{array}$ & $\begin{array}{l}\text { New England Journal of } \\
\text { Medicine }\end{array}$ & 569 & 27074377 \\
\hline 4 & $\begin{array}{l}\text { Schuler-Faccini L., } \\
\text { et al. }\end{array}$ & $\begin{array}{l}\text { Possible association between Zika virus } \\
\text { infection and microcephaly - Brazil, } \\
2015\end{array}$ & $\begin{array}{l}\text { Morbidity and Mortality } \\
\text { Weekly Report }\end{array}$ & 405 & 26820244 \\
\hline 5 & Calvet G., et al. & $\begin{array}{l}\text { Detection and sequencing of Zika virus } \\
\text { from amniotic fluid of fetuses with } \\
\text { microcephaly in Brazil: a case study }\end{array}$ & $\begin{array}{l}\text { The Lancet Infectious } \\
\text { Diseases }\end{array}$ & 388 & 26897108 \\
\hline 6 & Tang H., et al. & $\begin{array}{l}\text { Zika virus infects human cortical neural } \\
\text { progenitors and attenuates their growth }\end{array}$ & Cell Stem Cell & 357 & 26952870 \\
\hline 7 & $\begin{array}{l}\text { Oliveira Melo A.S., } \\
\text { et al. }\end{array}$ & $\begin{array}{l}\text { Zika virus intrauterine infection causes } \\
\text { fetal brain abnormality and microcephaly: } \\
\text { Tip of the iceberg? }\end{array}$ & $\begin{array}{l}\text { Ultrasound in Obstetrics } \\
\text { and Gynecology }\end{array}$ & 352 & 26731034 \\
\hline 8 & Brasil P., et al. & $\begin{array}{l}\text { Zika virus infection in pregnant women in } \\
\text { rio de janeiro }\end{array}$ & $\begin{array}{l}\text { New England Journal of } \\
\text { Medicine }\end{array}$ & 343 & 26943629 \\
\hline 9 & $\begin{array}{l}\text { Fauci A.S., Morens } \\
\text { D.M. }\end{array}$ & $\begin{array}{l}\text { Zika virus in the americas-yet another } \\
\text { arbovirus threat }\end{array}$ & $\begin{array}{l}\text { New England Journal of } \\
\text { Medicine }\end{array}$ & 343 & 26761185 \\
\hline 10 & Petersen L.R., et al. & Zika Virus & $\begin{array}{l}\text { New England Journal of } \\
\text { Medicine }\end{array}$ & 342 & 27028561 \\
\hline 11 & Cugola F.R., et al. & $\begin{array}{l}\text { The Brazilian Zika virus strain causes } \\
\text { birth defects in experimental models }\end{array}$ & Nature & 327 & 27279226 \\
\hline 12 & $\begin{array}{l}\text { Musso D., Gubler } \\
\text { D.J. }\end{array}$ & Zika virus & $\begin{array}{l}\text { Clinical Microbiology } \\
\text { Reviews }\end{array}$ & 315 & 27029595 \\
\hline 13 & Faria N.R., et al. & $\begin{array}{l}\text { Zika virus in the Americas: Early } \\
\text { epidemiological and genetic findings }\end{array}$ & Science & 303 & 27013429 \\
\hline 14 & Driggers R.W., et al. & $\begin{array}{l}\text { Zika virus infection with prolonged } \\
\text { maternal viremia and fetal brain } \\
\text { abnormalities }\end{array}$ & $\begin{array}{l}\text { New England Journal of } \\
\text { Medicine }\end{array}$ & 297 & 27028667 \\
\hline 15 & Garcez P.P., et al. & $\begin{array}{l}\text { Zika virus: Zika virus impairs growth in } \\
\text { human neurospheres and brain organoids }\end{array}$ & Science & 277 & 27064148 \\
\hline 16 & Cauchemez S., et al. & $\begin{array}{l}\text { Association between Zika virus and } \\
\text { microcephaly in French Polynesia, 2013- } \\
\text { 15: A retrospective study }\end{array}$ & The Lancet & 263 & 26993883 \\
\hline 17 & Lazear H.M., et al. & $\begin{array}{l}\text { A Mouse Model of Zika Virus } \\
\text { Pathogenesis }\end{array}$ & Cell Host and Microbe & 254 & 27066744 \\
\hline 18 & Miner J.J., et al. & $\begin{array}{l}\text { Zika Virus Infection during Pregnancy in } \\
\text { Mice Causes Placental Damage and Fetal } \\
\text { Demise }\end{array}$ & Cell & 252 & 27180225 \\
\hline 19 & Martines R.B., et al. & $\begin{array}{l}\text { Evidence of zika virus infection in brain } \\
\text { and placental tissues from two } \\
\text { congenitally infected newborns and two } \\
\text { fetal losses - Brazil, } 2015\end{array}$ & $\begin{array}{l}\text { Morbidity and Mortality } \\
\text { Weekly Report }\end{array}$ & 243 & 26890059 \\
\hline 20 & Qian X., et al. & $\begin{array}{l}\text { Brain-Region-Specific Organoids Using } \\
\text { Mini-bioreactors for Modeling ZIKV } \\
\text { Exposure }\end{array}$ & Cell & 242 & 27118425 \\
\hline
\end{tabular}


bioRxiv preprint doi: https://doi.org/10.1101/287169; this version posted April 5, 2018. The copyright holder for this preprint (which was not

\begin{tabular}{|c|c|c|c|c|c|}
\hline & Author & Article title & Source & $\begin{array}{l}\text { Cited } \\
\text { by }\end{array}$ & $\begin{array}{l}\text { Pubmed } \\
\text { ID }\end{array}$ \\
\hline 1 & Moore C.A., et al. & $\begin{array}{l}\text { Characterizing the pattern of anomalies in } \\
\text { congenital zika syndrome for pediatric } \\
\text { clinicians }\end{array}$ & JAMA Pediatrics & 82 & 27812690 \\
\hline 2 & Honein M.A., et al. & $\begin{array}{l}\text { Birth defects among fetuses and infants of } \\
\text { US women with evidence of possible zika } \\
\text { virus infection during pregnancy }\end{array}$ & $\begin{array}{l}\text { JAMA - Journal of the } \\
\text { American Medical } \\
\text { Association }\end{array}$ & 80 & 27960197 \\
\hline 3 & Pardi N., et al. & $\begin{array}{l}\text { Zika virus protection by a single low-dose } \\
\text { nucleoside-modified mRNA vaccination }\end{array}$ & Nature & 67 & 28151488 \\
\hline 4 & Bardina S.V., et al. & $\begin{array}{l}\text { Enhancement of Zika virus pathogenesis by } \\
\text { preexisting antiflavivirus immunity }\end{array}$ & Science & 66 & 28360135 \\
\hline 5 & Richner J.M., et al. & $\begin{array}{l}\text { Modified mRNA Vaccines Protect against } \\
\text { Zika Virus Infection }\end{array}$ & Cell & 58 & 28222903 \\
\hline 6 & Murray K.O., et al. & $\begin{array}{l}\text { Prolonged detection of zika virus in vaginal } \\
\text { secretions and whole blood }\end{array}$ & $\begin{array}{l}\text { Emerging Infectious } \\
\text { Diseases }\end{array}$ & 58 & 27748649 \\
\hline 7 & Krauer F., et al. & $\begin{array}{l}\text { Zika Virus Infection as a Cause of } \\
\text { Congenital Brain Abnormalities and } \\
\text { Guillain-Barré Syndrome: Systematic } \\
\text { Review }\end{array}$ & PLoS Medicine & 50 & \\
\hline 8 & $\begin{array}{l}\text { Abajobir A.A., et } \\
\text { al. }\end{array}$ & $\begin{array}{l}\text { Global, regional, and national age-sex } \\
\text { specific mortality for } 264 \text { causes of death, } \\
\text { 1980-2016: a systematic analysis for the } \\
\text { Global Burden of Disease Study } 2016\end{array}$ & The Lancet & 47 & \\
\hline 9 & $\begin{array}{l}\text { Gootenberg J.S., et } \\
\text { al. }\end{array}$ & $\begin{array}{l}\text { Nucleic acid detection with CRISPR- } \\
\text { Cas13a/C2c2 }\end{array}$ & Science & 47 & 28408723 \\
\hline 10 & Moreira J., et al. & $\begin{array}{l}\text { Sexually acquired Zika virus: a systematic } \\
\text { review }\end{array}$ & $\begin{array}{l}\text { Clinical Microbiology } \\
\text { and Infection }\end{array}$ & 46 & 28062314 \\
\hline 11 & $\begin{array}{l}\text { Reynolds M.R., et } \\
\text { al. }\end{array}$ & $\begin{array}{l}\text { Vital signs: Update on zika virus- } \\
\text { associated birth defects and evaluation of } \\
\text { all U.S. infants with congenital zika virus } \\
\text { exposure - U.S. zika pregnancy registry, } \\
2016\end{array}$ & $\begin{array}{l}\text { Morbidity and Mortality } \\
\text { Weekly Report }\end{array}$ & 44 & 28384133 \\
\hline 12 & $\begin{array}{l}\text { Bullard-Feibelman } \\
\text { K.M., et al. }\end{array}$ & $\begin{array}{l}\text { The FDA-approved drug sofosbuvir } \\
\text { inhibits Zika virus infection }\end{array}$ & Antiviral Research & 44 & 27902933 \\
\hline 13 & Shan C., et al. & $\begin{array}{l}\text { A live-attenuated Zika virus vaccine } \\
\text { candidate induces sterilizing immunity in } \\
\text { mouse models }\end{array}$ & Nature Medicine & 42 & 28394328 \\
\hline 14 & Bhatnagar J., et al. & $\begin{array}{l}\text { Zika virus RNA replication and persistence } \\
\text { in brain and placental tissue }\end{array}$ & $\begin{array}{l}\text { Emerging Infectious } \\
\text { Diseases }\end{array}$ & 41 & 27959260 \\
\hline 15 & Faria N.R., et al. & $\begin{array}{l}\text { Establishment and cryptic transmission of } \\
\text { Zika virus in Brazil and the Americas }\end{array}$ & Nature & 39 & 28538727 \\
\hline 16 & $\begin{array}{l}\text { Morrison T.E., } \\
\text { Diamond M.S. }\end{array}$ & $\begin{array}{l}\text { Animal models of Zika virus infection, } \\
\text { pathogenesis, and immunity }\end{array}$ & Journal of Virology & 36 & 28148798 \\
\hline 17 & Vos T., etal. & $\begin{array}{l}\text { Global, regional, and national incidence, } \\
\text { prevalence, and years lived with disability } \\
\text { for } 328 \text { diseases and injuries for } 195 \\
\text { countries, 1990-2016: A systematic } \\
\text { analysis for the Global Burden of Disease } \\
\text { Study } 2016\end{array}$ & The Lancet & 35 & \\
\hline 18 & Liu Y., et al. & $\begin{array}{l}\text { Evolutionary enhancement of Zika virus } \\
\text { infectivity in Aedes aegypti mosquitoes }\end{array}$ & Nature & 35 & 28514450 \\
\hline 19 & $\begin{array}{l}\text { Miner J.J., } \\
\text { Diamond M.S. }\end{array}$ & $\begin{array}{l}\text { Zika Virus Pathogenesis and Tissue } \\
\text { Tropism }\end{array}$ & Cell Host and Microbe & 35 & 28182948 \\
\hline 20 & $\begin{array}{l}\text { Elong Ngono A., } \\
\text { et al. }\end{array}$ & $\begin{array}{l}\text { Mapping and Role of the CD8+ T Cell } \\
\text { Response During Primary Zika Virus } \\
\text { Infection in Mice }\end{array}$ & Cell Host and Microbe & 34 & 28081442 \\
\hline
\end{tabular}


Table 2. Top 20 authors for Zika virus related publications 2015 to 2017

\begin{tabular}{|c|c|c|c|c|}
\hline Num & Author & Institutes & Publications & Proportion (\%) \\
\hline 1 & Wiwanitkit, V. & $\begin{array}{l}\text { University of Niš, Serbia; Hainan Medical University, } \\
\text { China }\end{array}$ & 136 & 3.00 \\
\hline 2 & Joob, B. & Medical Academic Center, Bangkok, Thailand & 52 & 1.14 \\
\hline 3 & Musso, D. & $\begin{array}{l}\text { Institut Louis Malardé, French Polynesia; Aix Marseille } \\
\text { Univ, France }\end{array}$ & 47 & 1.03 \\
\hline 4 & Benelli, G. & University of Pisa, Italy & 46 & 1.01 \\
\hline 5 & Diamond, M.S. & Washington University School of Medicine, USA & 36 & 0.79 \\
\hline 6 & Honein, M.A. & Centers for Disease Control and Prevention, USA & 33 & 0.73 \\
\hline \multirow{2}{*}{7} & Shi, P.Y. & University of Texas Medical Branch, USA & \multirow{2}{*}{32} & \multirow{2}{*}{0.70} \\
\hline & Weaver, S.C. & University of Texas Medical Branch, USA & & \\
\hline \multirow{2}{*}{8} & Qin, C.F. & Beijing Institute of Microbiology and Epidemiology, China & \multirow{2}{*}{29} & \multirow{2}{*}{0.64} \\
\hline & Vasilakis, N. & University of Texas Medical Branch, USA. & & \\
\hline \multirow[b]{2}{*}{9} & Govindarajan, M. & Annamalai University, India. & \multirow[b]{2}{*}{28} & \multirow[b]{2}{*}{0.62} \\
\hline & $\begin{array}{l}\text { Rodriguez- } \\
\text { Morales, A.J. }\end{array}$ & Universidad Tecnológica de Pereira, Colombia. & & \\
\hline 10 & Jamieson, D.J. & Emory University, USA & 27 & 0.59 \\
\hline \multirow[t]{2}{*}{11} & $\begin{array}{l}\text { Meaney-Delman, } \\
\text { D. }\end{array}$ & Centers for Disease Control and Prevention, USA & \multirow[t]{2}{*}{26} & \multirow[t]{2}{*}{0.57} \\
\hline & Wiwanitkit, S. & Wiwanitkit House, Thailand & & \\
\hline \multirow[t]{2}{*}{12} & Gao, G.F. & $\begin{array}{l}\text { Chinese Center for Disease Control and Prevention (China } \\
\text { CDC), China }\end{array}$ & \multirow[t]{2}{*}{25} & \multirow[t]{2}{*}{0.55} \\
\hline & Leparc-Goffart, I. & French Armed Forces Biomedical Research Institute, France & & \\
\hline \multirow{4}{*}{13} & Brasil, P. & Instituto Nacional de Infectologia Evandro Chagas, Brazil & \multirow{4}{*}{23} & \multirow{4}{*}{0.51} \\
\hline & Cordeiro, M.T. & $\begin{array}{l}\text { Aggeu Magalhaes Institute (Instituto Aggeu Magalhães- } \\
\text { IAM), Oswaldo Cruz Foundation (Fundação Oswaldo Cruz- } \\
\text { FIOCRUZ), Brazil. }\end{array}$ & & \\
\hline & Fischer, M. & Centers for Disease Control and Prevention, USA & & \\
\hline & Ventura, C.V. & $\begin{array}{l}\text { Altino Ventura Foundation, Brazil; HOPE Eye Hospital, } \\
\text { Brazil }\end{array}$ & & \\
\hline 14 & McCarthy, M. & Seattle, USA & 22 & 0.48 \\
\hline \multirow{3}{*}{15} & $\begin{array}{l}\text { Cao-Lormeau, } \\
\text { V.M. }\end{array}$ & $\begin{array}{l}\text { Institut Louis Malardé, French Polynesia; Aix Marseille } \\
\text { Univ, France }\end{array}$ & \multirow{3}{*}{21} & \multirow{3}{*}{0.46} \\
\hline & Deng, Y.Q. & Beijing Institute of Microbiology and Epidemiology, China & & \\
\hline & $\begin{array}{l}\text { Schmidt-Chanasit, } \\
\text { J. }\end{array}$ & $\begin{array}{l}\text { Bernhard-Nocht-Institut für Tropenmedizin, Germany; } \\
\text { German Centre for Infection Research (DZIF), Germany }\end{array}$ & & \\
\hline \multirow[t]{2}{*}{16} & Baud, D. & $\begin{array}{l}\text { Department Femme-Mère-Enfant, University Hospital, } \\
\text { Switzerland }\end{array}$ & \multirow[t]{2}{*}{20} & \multirow[t]{2}{*}{0.44} \\
\hline & Rasmussen, S.A. & Centers for Disease Control and Prevention, USA & & \\
\hline \multirow{4}{*}{17} & Oduyebo, $\mathrm{T}$. & Centers for Disease Control and Prevention, USA & & \\
\hline & Rossi, S.L. & University of Texas Medical Branch, USA & & \\
\hline & Shan, C. & University of Texas Medical Branch, USA. & 19 & 0.42 \\
\hline & Staples, J.E. & Centers for Disease Control and Prevention, USA & & \\
\hline & Pierson, T.C. & National Institutes of Health, Bethesda, USA & & \\
\hline 18 & Tanuri, A. & Universidade Federal do Rio de Janeiro, Brazil & 18 & 0.40 \\
\hline & Belfort, R. & Federal University of São Paulo, Brazil & & \\
\hline & Li, X.F. & Beijing Institute of Microbiology and Epidemiology, China & & \\
\hline & Moore, C.A. & University of Colorado, USA & & \\
\hline 19 & Petersen, E.E. & Centers for Disease Control and Prevention, USA & 17 & 0.37 \\
\hline & Petersen, L.R. & Centers for Disease Control and Prevention, USA & & \\
\hline & Powers, A.M. & Centers for Disease Control and Prevention, USA & & \\
\hline & Rodrigues, L.C. & London School of Hygiene and tropical Medicine, UK & & \\
\hline & Grobusch, M.P. & University of Amsterdam, The Netherlands. & & \\
\hline 20 & Hotez, P.J. & $\begin{array}{l}\text { National School of Tropical Medicine, Baylor College of } \\
\text { Medicine, USA }\end{array}$ & 16 & 0.35 \\
\hline & Xie, $\mathrm{X}$. & University of Texas Medical Branch, USA & & \\
\hline
\end{tabular}

